\title{
РАСПРЕДЕЛЕНИЕ ЗЕМЕЛЬНОГО ФОНДА РЕСПУБЛИКИ АЛТАЙ ПО КАТЕГОРИЯМ ЗЕМЕЛЬ
}

\section{Ангелина Михайловна Торбогошева}

Сибирский государственный университет геосистем и технологий, 630108, г. Новосибирск, Плахотного, 10, обучающийся, e-mail: angelina.torbogosheva@mail.ru

\section{Анастасия Леонидовна Ильиных}

Сибирский государственный университет геосистем и технологий, 630108, г. Новосибирск, ул. Плахотного, 10, кандидат технических наук, доцент кафедры кадастра и территориального планирования, тел. (383)344-31-73, e-mail: ilinykh_al@mail.ru

В статье рассмотрены особенности распределения земельного фонда Республики Алтай по категориям земель в сравнительном анализе за 2018 и 2019 годы.

Ключевые слова: земельный фонд, категории земель, использование земель

\section{DISTRIBUTION OF THE LAND FUNDS OF THE REPUBLIC OF ALTAI BY LAND CATEGORIES}

\section{Angelina M. Torbogosheva}

Siberian State University of Geosystems and Technologies, 10, Plakhotnogo St., Novosibirsk, 630108, Russia, Student, e-mail: angelina.torbogosheva@mail.ru

\section{Anastasiya L. Ilyinykh}

Siberian State University of Geosystems and Technologies, 10, Plakhotnogo St., Novosibirsk, 630108, Russia, Ph. D., Assoc. Prof., Department of Cadastre and Territorial Planning, phone: (383)344-31-73, e-mail: ilinykh_al@mail.ru

The article deals with the peculiarities of distribution of the land fund of the Altai Republic by categories of land in the comparative analysis for 2018 and 2019.

Keywords: land fund, classes of land, land use

В различных сферах деятельности земля используется по-разному, поэтому земельный фонд подразделяют на категории земель, которые различают по двум признакам: основному целевому назначению; правовому режиму использования и охраны. Следовательно, категория земель - это часть земельного фонда, выделяемая по основному целевому назначению, имеющая определенный правовой режим использования и охраны. Целевое назначение - это установленный законодательством порядок условия и предел использования земель для конкретных целей $[1,2]$.

Земли, находящиеся в пределах Республики Алтай, составляют земельный фонд Республики Алтай, который по состоянию на 01.01.2020 составляет 9290,3 тыс. га и включает в себя все семь категорий земель (таблица) [3]. 
Распределение земельного фонда Республики Алтай по категориям земель по состоянию на 01.01.2020

\begin{tabular}{|c|c|c|c|c|c|}
\hline № п/п & $\begin{array}{c}\text { Наименование катего- } \\
\text { рии земель }\end{array}$ & $\begin{array}{c}2018 \text { г., } \\
\text { тыс. га }\end{array}$ & $\begin{array}{c}2019 \text { г., } \\
\text { тыс. га }\end{array}$ & $\begin{array}{c}2019 \text { г. к } \\
2018 \text { г. }\end{array}$ & $\begin{array}{c}\text { в } \\
\text { про- } \\
\text { цен- } \\
\text { тах } \\
\text { от } \\
\text { об- } \\
\text { щей } \\
\text { пло- } \\
\text { щади }\end{array}$ \\
\hline 1 & $\begin{array}{c}\text { Земли сельскохозяй- } \\
\text { ственного назначения }\end{array}$ & 2640,2 & 2645 & 4,8 & 28,5 \\
\hline 2 & $\begin{array}{c}\text { Земли населенных пунк- } \\
\text { тов }\end{array}$ & 47,3 & 47,3 & 0 & 0,5 \\
\hline 3 & $\begin{array}{c}\text { Земли промышленности, } \\
\text { транспорта...и иного } \\
\text { специального назначе- } \\
\text { ния }\end{array}$ & 11 & 11,1 & 0,1 & 0,1 \\
\hline 4 & $\begin{array}{c}\text { Земли особо охраняе- } \\
\text { мых территорий и объ- } \\
\text { ектов }\end{array}$ & 1143,8 & 1143,8 & 0 & 12,3 \\
\hline 5 & Земли лесного фонда & 3754,1 & 3754,1 & 0 & 40,4 \\
\hline 6 & Земли водного фонда & 27,6 & 27,6 & 0 & 0,3 \\
\hline 7 & Земли запаса & 1666,3 & 1661,4 & $-4,9$ & 17,9 \\
\hline & Итого & 9290,3 & 9290,3 & 0 & 100 \\
\hline
\end{tabular}

Земли сельскохозяйственного назначения. Площадь земель сельскохозяйственного назначения составляет 2645 тыс. га или 28,5\% земельного фонда Республики Алтай.

Площадь земель категории сельскохозяйственного назначения в 2019 году изменилась на 4,8 га. Увеличение площади данных земель осуществлено за счет перевода 4867 га земель из категории «Земли запаса» в категорию земель «Земли сельскохозяйственного назначения».

Уменьшение площади произошло за счет перевода земель площадью 20 га в категорию земель населенных пунктов, 42 га в категорию земель промышленности и иного специального назначения. Земли данной категории в установленном порядке отводились под расширение границ населенных пунктов, строительство новых и расширение существующих дорог регионального и местного значения.

Земли населенных пунктов. Общая площадь земель 247 населенных пунктов РА на конец 2019 года составила 47,3 тыс. га, из которых в границах г. Горно-Алтайска находится 9,1 тыс. га, в границах сельских населенных пунктов 38,2 тыс. га. 
Земли населенных пунктов Республики Алтай в 2019 году увеличились на 20 га, в основном, за счет земель сельскохозяйственного назначения.

Земли промышленности, энергетики, транспорта, связи, радиовещания, телевидения, информатики, землями для обеспечения космической деятельности, землями обороны, безопасности и землями иного специального назначения (земли промышленности). Общая площадь земель промышленности составляет 11,1 тыс. га, из которых 5,6 тыс. га $(51,8 \%)$ земель занимают земли автомобильного транспорта, 1,8 тыс. га или $16,7 \%$ земель данной категории заняты промышленными предприятиями.

В 2019 году земли промышленности увеличились на 42 га за счет земель сельскохозяйственного назначения.

Земли особо охраняемых территорий и объектов. На земли особо охраняемых территорий и объектов приходится 1143,8 тыс. га или $12,3 \%$ от общей площади республики.

Земли лесного фонда. Наибольшую долю земель в земельном фонде Республики Алтай составляют земли лесного фонда 3754,1 тыс. га (40,4\%). Это обусловлено, в первую очередь, географическим положением, а именно: Республика Алтай расположена в горной местности.

За 2019 год площадь земель лесного фонда не изменилась.

Земли водного фонда. Земли водного фонда на территории Республики Алтай занимают 27,6 тыс. га или 0,3\% всей площади, их которых 27,1 га $(98,2 \%)$ находится под водой.

За 2019 год площадь земель данной категории также не изменилась.

Земли запаса. На территории Республики Алтай 1661,4 тыс. га (17,9\%) земель отнесены к категории «Земли запаса».

Уменьшение площади земель данной категории связано с переводом таких земель в иные категории. Так, в 2019 году4,9 тыс. га земель запаса переведены в категорию земель сельскохозяйственного назначения.

Повсеместно встречается потребительское отношение собственников к использованию земли. Одним из итогов проводимых земельных реформ было повсеместное разрушение колхозов и совхозов. Получила распространение система фермерского хозяйства. Наряду с этим, наиболее распространённой формой хозяйствования в крае являются личные подсобные хозяйства (ЛПХ), встречаются производственные кооперативы, обладающие общими чертами с прежними колхозами.

На 1 января 2020 г. площадь земель, находящихся в государственной и муниципальной формах собственности в республике, составила 91,3\% (8486,1 тыс. га). В собственности граждан находилось $6,9 \%$ (640,7 тыс. га) земельного фонда и в собственности юридических лиц - 1,8\% (163,5 тыс. га) земельного фонда республики. Большую долю из них составляют земли сельхозназначения.

Вместе с тем, невостребованные земельные доли составляют 327,5 тыс. га $(52,2 \%)$. Существуют заброшенные земли, то есть не обрабатываемые, пустующие, незасеваемые. Отсутствие фактического «хозяина» земель генерирует проблемы, в том числе экологического характера. 
Низкая экономическая состоятельность сельхозпроизводителей приводит к истощению земель и их деградации (интенсификации эрозийных процессов, уменьшению продуктивности). Собственники мелких землепользований не в силах проводить противоэрозионные и мелиоративные мероприятия.

Значительную опасность для состояния сельскохозяйственных земель представляет понижение общего уровня культуры земледелия и неисполнение обязательных почвозащитных и иных природоохранных мероприятий, вызванных финансовыми трудностями, низкой поддержкой сельскохозяйственных производителей со стороны государства.

Из вышеуказанных данных можно сделать вывод, что наиболее значительным изменениям подвержены земли сельскохозяйственного назначения и земли запаса. Как правило, эти изменения находятся в прямой зависимости от потребности в них субъектов, занимающихся сельскохозяйственным производством и изменения в одной категории земель приводят к соответствующим изменениям в другой.

\section{БИБЛИОГРАФИЧЕСКИЙ СПИСОК}

1. Кошелева Т. Н. Кадастровый учёт недвижимости в сервисе: учебное пособие [Текст] / Т. Н. Кошелева, Е. В. Грозовская - СПб.: Изд-во "КультИнформПресс", 2018. $173 \mathrm{c}$.

2. Земельный кодекс Российской Федерации [Электронный ресурс]: федер. закон от 25.10.2001 N 136-Ф3. - Доступ из справ. - правовой системы «КонсультантПлюс».

3. Доклад о состоянии и об охране окружающей среды Республики Алтай в 2019 году. 2020 г. Министерство природных ресурсов, экологии и туризма Республики Алтай [Электронный ресурс]. - Режим доступа: https://www.mpr-ra.ru/. - Загл. с экрана.

(C) А. М. Торбогошева, А. Л. Ильиных, 2021 